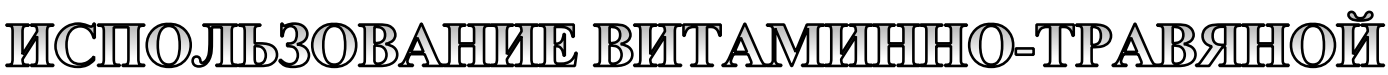

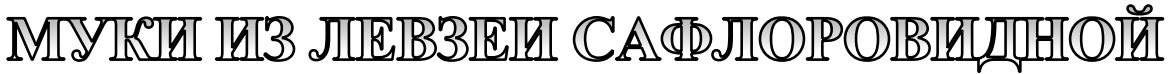

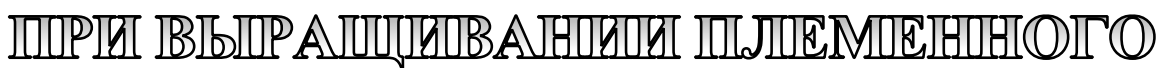

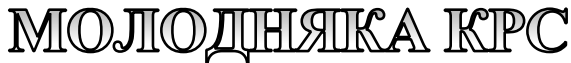

Н.А. Морозков, Пермский научно-исследовательский институт сельского хозяйства Д.А. Матолинец, Пермский научно-исследовательский институт сельского хозяйства И.В. Сергеев, Пермский государственный аграрно-технологический университет им. академика Д.Н. Прянишникова

Получены экспериментальные данные о влиянии скармливания витаминнотравяной муки (ВТМ) из левзеи сафлоровидной на переваримость кормов рациона и рост молодняка крупного рогатого скота (КРС). В результате скармливания ВТМ из левзеи сафрлоровидной коэффициенты переваримости сырого протеина, сырой клетчатки, безазотистых экстрактивных веществ и органического вещества в целом оказались выше у тёлочек 1-3-месячного возраста 1-й и 2-й опытных групп по сравнению с животными контрольной группы. Наблюдалось лучшее развитие тёлочек первой опытной группы, которые получали по 0,075 кгВТМ. Абсолютный прирост живой массы животных 1-й опытной группы составил 147,7 кг, что на 10,46\% больше $(p<0,05)$, а во 2-й опытной - на 9,86\% больше $(p<0,05)$, чем в контрольной.

Ключевые слова: молодняк КРС, левзея сафлоровидная, период выращивания, каротин, абсолютный прирост, 20-гидроксиэкдизо, переваримость.

Обеспечить необходимый уровень производства молока можно только при интенсивном выращивании молодняка крупного рогатого скота. С этой целью нужно создавать в различные периоды индивидуального развития животных оптимальные условия кормления и содержания, обеспечивающие хорошее развитие организма на морфологическом, физиологическом, биохимическом и метаболическом уровнях и способствующие наиболее полной реализации и проявлению высокого генетического потенциала молочной продуктивности во взрослом состоянии $[5,7]$.
При постоянном усилении техногенной и антропогенной нагрузки на организм животных, особенно в условиях промышленного содержания, приводит к смещению обменных процессов в организме, нарушениям защитных барьеров, созданных в процессе многовековой эволюции. Это требует внесения некоторых корректив в организацию полноценного кормления сельскохозяйственных животных. В этих условиях важное значение имеет не только полноценность рационов по основным показателям питательности кормов, но и обогащение их биологически активными веществами. Выполняя 
роль катализаторов, они повышают естественную резистентность организма, нормализуют обмен веществ, способствуют лучшему усвоению питательных веществ корма, более интенсивному росту и развитию животных [4].

Известна целая группа биологически активных веществ (БАВ) и препаратов, способных стимулировать резистентность организма животных и человека, объединённых одним термином - адаптогены. Особое положение в списке адаптогенов растительного происхождения занимают экдистероиды [6]. На сегодняшний день известно, что большое содержание экдистероидов находится в левзее сафлоровидной, серпухе венценосной и других растениях $[1,2,9,11,14,12]$.

Основными действующими веществами левзеи сафлоровидной (синонимы: рапонтикум, маралий корень, Leuzea, Rhaponticum carthamoides, maral root) является комплекс экдистероидов, которые регулируют метаболические процессы, не являясь при этом истинными гормонами. Физиологические эффекты экдистероидов на организм теплокровных животных весьма разнообразны. Они регулируют минеральный, углеводный, липидный и белковый обмен, стимулируют кроветворную функцию (эритропоэз), биосинтез ДНК в лимфоцитах, усиливают регенерацию и увеличивают концентрацию эритроцитов, гемоглобина и фракции гамма-глобулинов в крови.

Продукт из левзеи сафлоровидной характеризуется значительной широтой оптимальных дозировок. Доза, используемая в профилактических целях, равна 0,1-1,0 г препарата на 1 т живой массы. Доза 2 г/т в пересчете на 20-гидроксиэкдизон составляет $10^{-11} \mathrm{M}$ (при содержании 0,25 \% действующих веществ в сухом веществе продукта). Исходя из производственных или иных целей, а также видов животных с различной интенсивностью обмена веществ, средние дозы могут быть уменьшены или увеличены в 10-100 раз. Применяемые в прак- тике животноводства дозы рапонтика являются эмпирическими и составляют от 250 г до 1 кг в сутки на одну голову по сухому веществу [13].

Употребляется перорально - в составе сухих кормов или в виде настоя на горячей воде, а также в качестве спиртовых экстрактов и настоев (в соотношении 1:20 - масса/объем). Малые дозы левзеи скармливаются в любое время суток, длительность непрерывного приема не ограничена - до 2-3 лет. Большие дозы используются в утреннее и дневное время. Длительность приема для достижения значимого эффекта при этом составляет 7-10 дней. Разовый курс в профилактических целях, в зависимости от величины и частоты доз, может достигать 30-60 дней, после чего рекомендуется делать перерыв на 30-90 дней. У стельных животных используются средние дозы - начиная за 10 дней до предполагаемой даты отела и в течение 30 дней после родов [13].

Актуальным является использование экологически безопасного растительного сырья, обладающего повышенным иммуностимулирующим действием. Таким иммуностимулирующим кормовым сырьём может быть левзея сафлоровидная.

Цель исследований - получить экспериментальные данные о влиянии скармливания витаминно-травяной муки из зелёной массы левзеи сафлоровидной на переваримость кормов рациона и рост молодняка КРС 1-2-3-месячного возраста.

\section{Задачи исследований:}

1. Изучить качественный состав травяной муки из зелёной массы левзеи сафлоровидной.

2. Определить переваримость кормов рациона молодняка КРС 3-месячного возраста.

3. Выявить влияние скармливания травяной муки из зелёной массы левзеи сафлоровидной на прирост живой массы молодняка КРС. 


\section{Методика и условия проведения исследований}

В 2017 году для решения поставленных задач были проведены научно-хозяйственный и физиологический опыты на Лобановском молочном комплексе ООО «Русь» Пермского района. Исследования проводились на молодняке КРС черно-пестрой голштинизированной породы в период с 31-дневного возраста по 81-й день выращивания. Выявлены результаты роста и развития тёлочек по 183-й день выращивания.

Для введения в рацион кормления молодняка КРС кормов, обладающих повышенными иммуностимулирующими свойствами, Пермским НИИСХ была выращена кормовая культура левзея сафлоровидная, высушена и размолота до состояния муки. Проведены исследования по определению биохимического состава в аналитической лаборатории Пермского НИИСХ и содержание 20-гидроксиэкдизона в аналитической лаборатории института биологии Коми НЦ УрО РАН (г. Сыктывкар).

Предметом исследований являлся рацион кормления молодняка КРС с использованием кормов собственного производства сбалансированный по основным элементам питательности с заменой части рациона из состава объёмистых кормов травяной мукой из зелёной массы левзеи сафлоровидной.

Опыт проводился методом парных аналогов по методике А.И. Овсянникова (1976) [10]. Было отобрано 30 голов молодняка КРС (тёлочки), из которых сформировали три одинаковые группы по 10 голов в каждой. Опыт включал уравнительный период 15 дней (со 16-го по 30-й день выращивания), учетный - 50 дней (с 31-го по 81-й день выращивания) и заключительный - с 81-го по 183-й день выращивания. В каждом опыте основной хозяйственный рацион кормления (OP) и условия содержания в опытных и контрольной группах одинаковые и типичны для данного комплекса. Опытным группам в составе ОР выделялась травяная мука из зелёной массы левзеи сафлоровидной в дозе:1-я опытная группа - по 0,075 кг на голову в сутки; 2-я опытная группа - из расчёта 0,150 кг на голову в сутки в период с 31-дневного возраста по 81-й день выращивания. Травяную муку скармливали в смеси с концентрированными кормами. Длительность скармливания ВТМ из левзеи сафлоровидной составила 50 дней.

\section{Результаты исследований}

Перед началом проведения научно-хозяйственного опыта был проведён анализ питательности витаминно-травяной муки (ВТМ) из зелёной массы левзеи сафлоровидной (табл. 1).

Анализ биохимического состава ВТМ из зелёной массы левзеи сафлоровидной показал, что содержание 20-го гидроксиэкдизона составило $0,39 \%$ в сухом веществе корма (при норме 0,25\%). В 2017 году зелёную массу левзеи сафлоровидной убирали 1 раз за сезон - 23 июня.

Следует отметить повышенное содержание сахара и обменной энергии в

Биохимический состав витаминно-травяной муки (ВТМ)

Таблица 1

из зелёной массы левзеи сафлоровидной (на АСB)

\begin{tabular}{|c|c|c|c|c|c|c|c|c|c|c|c|}
\hline $\begin{array}{c}\text { Вид } \\
\text { корма }\end{array}$ & $\begin{array}{c}\mathrm{CB}, \\
\%\end{array}$ & $\begin{array}{c}\text { C世, } \\
\%\end{array}$ & $\begin{array}{c}\text { СП, } \\
\%\end{array}$ & $\begin{array}{l}\text { CK, } \\
\%\end{array}$ & $\begin{array}{l}\text { Caxap, } \\
\%\end{array}$ & $\begin{array}{l}\mathrm{Ca}, \\
\mathrm{r} / \mathrm{kr}\end{array}$ & $\begin{array}{l}P \\
\Gamma / k r\end{array}$ & $\begin{array}{l}\text { Каро- } \\
\text { тин, } \\
\text { Мг/Кг }\end{array}$ & $\begin{array}{l}\text { Кор.ед., } \\
\text { кг }\end{array}$ & $\begin{array}{c}\text { ОЭ, } \\
\text { МДж/кг }\end{array}$ & $\begin{array}{c}20 \text { гидро- } \\
\text { ксиэкд- } \\
\text { изон, } \%\end{array}$ \\
\hline $\begin{array}{c}\text { ВТМ (левзея } \\
\text { сафроровидная } \\
\text { 1-й укос) }\end{array}$ & 80,8 & 1,35 & 17,3 & 21,5 & 5,7 & 15,0 & 3,1 & 91,4 & 0,83 & 10,14 & 0,39 \\
\hline $\begin{array}{c}\text { Зоотехн. } \\
\text { норма в } 1 \text { кг CB }\end{array}$ & 83,0 & 2,53 & 19 & 23 & 3,01 & 6,3 & 2,4 & 100 & 0,80 & 10,00 & $0,25-0,45$ \\
\hline
\end{tabular}


сухом веществе ВТМ из левзеи сафлоровидной. Содержание сахара составляло 5,7\% (норма 3,01\%), что выше зоотехнической нормы на 89,37\%. Содержание обменной энергии находилось на уровне 10,14 МДж, что превышает норму и свидетельствует о высокой питательности корма.

Содержание каротина в ВТМ из левзеи сафлоровидной было на уровне 91,4 мг/кг, (при норме 100 мг/кг для разнотравья). Недобор каротина связан как обычно с временем уборки зелёной массы в дневные часы, когда идёт снижение каротина в травостое.

Данные химического состава кормов не дают полного представления о питательности, так как не учитывают их действие на животный организм. Одним из методов изучения взаимодействия корма и животного является определение переваримости.

С целью определения переваримости и использования питательных веществ рационов в период с 18 по 24 октября 2017 года на фоне научно-хозяйственного опыта был проведен физиологический опыт на 3 тёлочках-аналогах, отобранных по методике А.И. Овсянникова (1976) [10] из каждой эксперименталь- ной группы. Корм каждому животному задавался индивидуально. Ежедневный учет съеденных животными кормов и анализ их биохимического состава позволили установить количество питательных веществ, потребленных за период балансового опыта (табл. 2).

Из данных табл. 2 следует, что животные подопытных групп потребили практически одинаковое количество сухого и органического вещества, сырого протеина. Во всех опытных группах стоит проблема с обеспеченностью сахаром, сырым жиром и каротином. Сахаропротеиновое отношение находилось в пределах 0,25 при норме 0,89. Обеспеченность сырым жиром составляла в контрольной и опытных группах 65,16\% и 65,81 - 63,93\% соответственно. Сбалансировать рацион телят по сырому жиру можно было путём дополнения рецепта комбикорма более качественными зерновыми ингредиентами.

Показателем использования подопытными тёлками питательных веществ испытуемых рационов являются коэффициенты переваримости, определяемые отношением переваренных веществ к потребленным, в процентах (рисунок).

Таблица 2

Рационы кормления тёлок 3-месячного возраста с живой массой 105-110 кг, со среднесуточным приростом 850 г, по фактическому потреблению кормов, на голову, $(\bar{X} \pm S \bar{x})$

\begin{tabular}{|c|c|c|c|c|}
\hline \multirow{2}{*}{ Показатель } & \multirow{2}{*}{ Норма } & \multicolumn{3}{|c|}{ Группа } \\
\cline { 3 - 4 } & & контрольная & 1-я опытная & 2-я опытная \\
\hline Сено, кг & 1,5 & - & - & - \\
\hline Силос, кг & 2,5 & $1,7 \pm 0,28$ & $1,9 \pm 0,14$ & $2,4 \pm 0,27$ \\
\hline $\begin{array}{c}\text { Комбикорм } \\
\text { «Култаевский», кг }\end{array}$ & 1,5 & $2,6 \pm 0,24$ & $2,6 \pm 0,21$ & $2,3 \pm 0,17$ \\
\hline ВТМ (левзея сафрлоровидная), кг & - & 0,0 & $0,075 \pm 0,00$ & $0,150 \pm 0,00$ \\
\hline \multicolumn{4}{|c|}{ Содержание в кормах } \\
\hline Сухого вещества, кг & 2,7 & $2,49 \pm 0,23$ & $2,60 \pm 0,76$ & $2,48 \pm 0,43$ \\
\hline ЭКЕ & 2,8 & $3,20 \pm 0,18$ & $3,54 \pm 0,63$ & $2,97 \pm 0,39$ \\
\hline Обменной. энергии, МДж & 29,8 & $31,28 \pm 0,43$ & $32,24 \pm 0,53$ & $30,45 \pm 0,17^{*}$ \\
\hline Сырого протеина, г & 598 & $702,70 \pm 2,23$ & $719,00 \pm 2,32$ & $668,80 \pm 1,41$ \\
\hline Перев. протеина, г & 460 & $540,50 \pm 2,56$ & $553,00 \pm 3,52$ & $514,40 \pm 3,42$ \\
\hline Сырой клетчатки, г & 542 & $161,50 \pm 1,37$ & $185,20 \pm 2,58$ & $216,80 \pm 1,43$ \\
\hline Кальция, г & 29 & $30,50 \pm 0,32$ & $31,90 \pm 0,45$ & $32,50 \pm 0,38^{*}$ \\
\hline Фосфора, г & 18 & $18,40 \pm 0,09$ & $18,70 \pm 0,11^{* *}$ & $18,60 \pm 0,008$ \\
\hline Сахара, г & 410 & $134,80 \pm 1,12$ & $139,20 \pm 1,23$ & $130,40 \pm 1,17$ \\
\hline Сырого жира, г & 277 & $180,50 \pm 0,43$ & $182,30 \pm 0,55$ & $177,10 \pm 0,16^{*}$ \\
\hline Каротина, мг & 80 & $74,30 \pm 0,05$ & $81,50 \pm 0,10$ & $91,20 \pm 0,09$ \\
\hline
\end{tabular}

Примечание: * $-p<0,05 ;{ }^{* *}-p<0,01 ;{ }^{* * *}-p<0,001$. 


\section{Коэффициенты переваримости питательных веществ корма,\%}

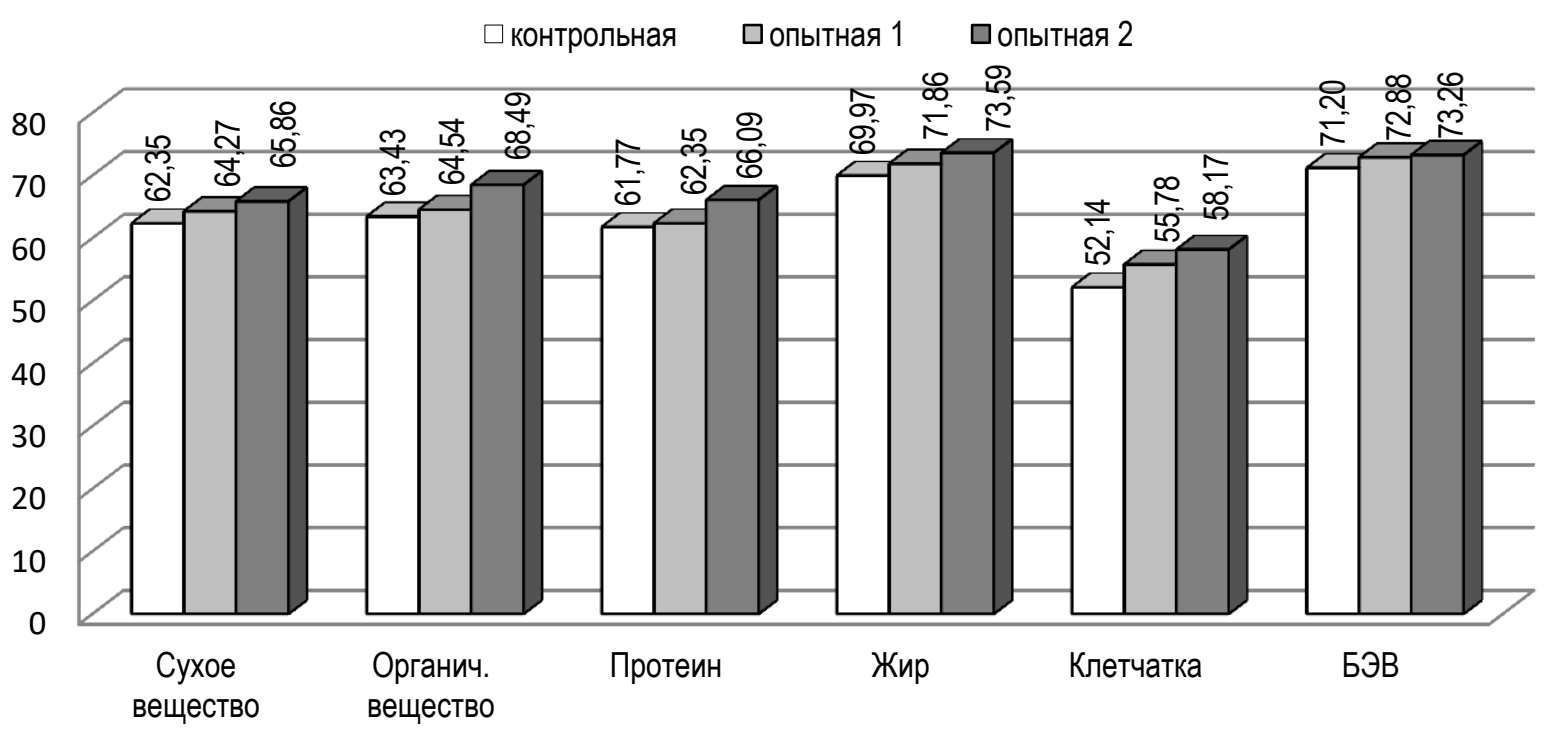

Рис. Переваримость питательных веществ рационов

Коэффициент переваримости сухого вещества у телок 2-й опытной группы был больше на $2,88 \%$, органического вещества - на $3,11 \%$, сырого протеина - на $2,14 \%$, сырого жира - на $1,77 \%$ и БЭВ на $4,08 \%(\mathrm{p}<0,05)$, чем в контроле. Очевидно, это обусловлено оптимальным сочетанием питательных веществ животного и растительного происхождения. Сырая клетчатка переваривалась лучше телками 1-й и 2-й опытных групп на 9,62\% и $8,19 \%$ соответственно, чем в контрольной, что, по-видимому, связано с большей активизацией рубцовой микрофлоры.

Поскольку коэффициенты переваримости сырого протеина, сырой клетчатки, безазотистых экстрактивных веществ оказались выше у тёлок 2-й и 1-й опытных групп, то можно предполагать, что скармливание ВТМ из левзеи сафлоровидной оказало положительное влияние на процессы пищеварения в желудочнокишечном тракте подопытных животных.

Одним из главных условий при интенсивном выращивании молодняка крупного рогатого скота является обильное кормление. При этом разный уровень кормления оказывает заметное влияние на обмен веществ в организме животных и их физиологическое состояние. В частности, с повышением уровня кормления усиливаются обменные процессы, ускоряя их рост и развитие $[3,8]$. В табл. 2 представлены показатели роста подопытных животных в период научно-хозяйственного опыта.

Постановочная живая масса подопытного молодняка КРС находилась в пределах 32,8-33,4 кг, то есть разность между ними не превысила 1,1\% (составила $1,018 \%$ ), что подтверждает правильность подбора аналогов по живой массе.

В результате проведения эксперимента выявлено влияние скармливания ВТМ из левзеи сафлоровидной на рост и развитие молодняка КРС (табл. 3).

Средняя живая масса тёлок при постановке на физиологический опыт составила 79,1 кг. В 3-месячном возрасте тёлочки 1-й опытной группы по живой массе превосходили животных контрольной группы на 4,8 кг (p<0,001), 2-й - на 1,9 кг (p<0,01). К концу научно-хозяйственного опыта живая масса животных имела некоторые различия. В возрасте 6 месяцев живая масса телок 1-й опытной группы составила 180,9 кг, что на $8,26 \%$ больше, у животных 2-й опытной - 179,7 кг, что на 7,54\% больше, чем в контроле. Абсолютный прирост 
Живая масса и её прирост у подопытных тёлочек

\begin{tabular}{|c|c|c|c|}
\hline \multirow{2}{*}{ Показатель } & \multicolumn{3}{|c|}{ Группа } \\
\cline { 2 - 4 } & контрольная $\mathbf{n = 1 0}$ & 1-я опытная $\mathbf{n = 1 0}$ & 2-я опытная $\mathbf{n = 1 0}$ \\
\hline Живая масса(кг) в возрасте, мес. & & & \\
\hline При рождении & $33,40 \pm 0,61$ & $33,10 \pm 0,45$ & $32,80 \pm 0,58$ \\
\hline 1 & $47,40 \pm 1,97$ & $47,30 \pm 1,15$ & $46,80 \pm 1,45$ \\
\hline 2 & $61,40 \pm 1,98$ & $63,50 \pm 0,94$ & $62,50 \pm 1,18$ \\
\hline 3 & $76,50 \pm 1,95$ & $81,30 \pm 0,24^{* * *}$ & $79,40 \pm 0,37^{* *}$ \\
\hline 6 & $167,20 \pm 3,56$ & $180,90 \pm 1,44$ & $179,70 \pm 1,18$ \\
\hline Абсолютный прирост, кг & $133,80 \pm 2,82$ & $147,70 \pm 1,78^{*}$ & $146,90 \pm 1,98^{*}$ \\
\hline Среднесуточный прирост, г & $731,00 \pm 7,78$ & $807,00 \pm 1,42^{* * *}$ & $802,00 \pm 1,56^{* *}$ \\
\hline
\end{tabular}

Примечание: ${ }^{*}-p<0,05 ;{ }^{* *}-p<0,01 ;{ }^{* * *}-p<0,001$.

живой массы животных 1-й опытной группы составил 147,7 кг, что на $10,46 \%$ больше $(\mathrm{p}<0,05)$, а во 2-й опытной - на 9,86\% больше $(\mathrm{p}<0,05)$, чем в контрольной.

Среднесуточный прирост за период опыта составил соответственно в контрольной группе - 731 г, 1-й опытной - 807 г и 2-й опытной 802 г, при затратах кормов на 1 кг прироста 5,1 - 4,7 - 4,6 энергетических кормовых единиц соответственно. По среднесуточному приросту живой массы тёлочки контрольной группы уступали животным 1-й опытной группы на $8,8 \%$ $(p<0,01), 2-и ̆-$ на 3,6\% ( $<<0,001)$.

\section{Выводы}

1. Одной из серьезных проблем в технологии кормления молодняка КРС на животноводческом комплексе является отсутствие обеспеченности в рационе кормления телят до 6-месячного возраста качественного сена и силоса.
2. В результате скармливания ВТМ из зелёной массы левзеи сафлоровидной в период с 31-го по 81-й день выращивания создаются более благоприятные условия для жизнедеятельности рубцовой микрофлоры, что способствует большей переваримости не только сухого вещества рациона у тёлок 2-й опытной группы на $2,38 \%(1,84 \%)$, чем у тёлок 1 -й опытной группы, и на $2,88 \%(2,22 \%)$ по сравнению с контролем, но и органического вещества - на $0,76 \%(0,63 \%)$ и на $3,12 \%(2,51 \%)$ соответственно.

3. По результатам полученных данных абсолютного прироста молодняка КРС 1-й и 2-й опытных и контрольной групп за период опыта можно сделать вывод, что скармливание витаминно-травяной муки из зелёной массы левзеи сафлоровидной в период с 31-го по 81-й день выращивания тёлочек достоверно повлияло на увеличение абсолютного прироста молодняка КРС.

\section{Библиографический список}

1. Ануфриева Э.Н., Володин В.В., Носов А.М., Лафон Р., Гарсиа М. Фитоэкдистероиды культуры тканей серпухи венценосной // Международное совещание по фитоэкдистероидам. - Сыктывкар, 1996. - С. 85-86.

2. Ахрем А.А., Ковганко Н.В. Экдистероиды: химия и биологическая активность. - Минск: Наука и техника, 1989. - $327 \mathrm{c.}$

3. Галиев Б.Х. Разработка научных и практических основ оптимизации типов кормления различных полновозрастных групп мясного скотоводства в степной зоне Южного Урала: дис. ... д-ра с/х наук. - Оренбург, 1998. - 380 с.

4. Завьялова В.К. Использование пробиотиков в кормлении телят молочного периода // Современное развитие зоотехнической науки и практики животноводства: матер. Регионал. науч.-практ. конф. Пермь, 2012. - С. 25-28.

5. Зборовский Л.В. Интенсивное выращивание тёлок. - М.: Росагропромиздат, 1991. - 238 с.

6. Ивановский A.A. Иммуностимуляторы и их роль в повышении резистентности животных к болезням. - Киров: Зональный НИИСХ Северо-Востока, 2005. - 68 с. 
7. Косилов В.И., Губашев Н.М., Насамбаев Е.Г. Повышение мясных качеств казахского белоголового скота путём скрещивания // Изв. Оренбургского гос. аграрного ун-та. - 2007. - Т. 1. - № 13-1. C. 91-93.

8. Левахин В.И. Мясное скотоводство: проблемы и пути их решения // Вестник мясного скотоводства / Тр. Всерос. НИИ мясного скотоводства. - Оренбург, 2003. - Вып. 55. - С. 3-9.

9. Мишуров В.П., Рубан Г.А., Скупченко Л.А. Серпуха венценосная, как продуцент экдистероидов в Республике Коми // Международное совещание по фитоэкдистероидам. - Сыктывкар, 1996. - С. 92.

10. Овсянников А.И. Основы опытного дела в животноводстве. - М.: Колос, 1976. - 304 с.

11. Тимофеев Н.П. Результаты практического внедрения в свиноводство рапонтика сафлоровидного в качестве экдистероидного сырья // Материалы III Международной конференции по селекции, технологии возделывания и переработки нетрадиционных растений. - Симферополь, 1994. C. $166-167$.

12. Тимофеев Н.П., Ивановский А.А. Анаболический эффект малых доз препаратов рапонтика // Международное совещание по фитоэкдистероидам. - Сыктывкар, 1996. - С. 133.

13. Тимофеев Н.П. Новая технология и производственная эффективность высококачественного сырья рапонтика сафлоровидного // III международный симпозиум «Новые и нетрадиционные растения и перспективы их практического использования». - Т. 3. - Пущино, 1999а. - C. 465-467.

14. Тимофеев Н.П. Биологические основы введения в культуру Rhaponticum cartamoides (Wild) Iljin в подзоне средней тайги Европейского Северо-Востока России: автореф. дис.... канд. биол. наук. Сыктывкар, 2000. - 24 с.

\title{
THE USE OF VITAMIN-HERBAL FLOUR FROM LEUZEA SAFFLOWER, RHAPONTICUM CARTHAMOIDES (Willd) IN RAISING PEDIGREE YOUNG CATTLE
}

\author{
N.A. Morozkov ${ }^{1}$, D.A. Matolinets ${ }^{1}$, I.V. Sergeev ${ }^{2}$ \\ ${ }^{1}$ Perm Scientific Research Institute of Agriculture \\ ${ }^{2}$ Perm State Agro-Technological University
}

The article presents experimental data on the effect of feeding vitamin-herbal flour (VHF) from leuzea safflower to cattle on food ration digestion and the growth of young cattle (1-3 months old). As a result of feeding VHF to cattle the digestibility coefficients of crude protein, crude cellulose, nitrogen-free extractive compounds and organic matter in general were higher for the first and the second test cattle groups, compared with the animals of the control group. A better development of the calves in the first test group that received $0,075 \mathrm{~kg}$ of VHF each was observed. The absolute weight increment for the animals in the first test group was $147,7 \mathrm{~kg}$, that is $10,46 \%$ more $(\mathrm{p}<0,05)$, and in the second group $-9,86 \%$ more $(\mathrm{p}<0,05)$ compared with the control group.

Keywords: young cattle, Leuzea safflower, the period of raising, carotene, absolute increment, 20-hydroxy ecdyzone, digestibility.

\section{Сведения об авторе}

Морозков Николай Александрович, кандидат сельскохозяйственных наук, старший научный сотрудник лаборатории кормопроизводства, животноводства и ветеринарной медицины, Пермский научно-исследовательский институт сельского хозяйства - филиал Пермского федерального исследовательского центра УрО РАН (Пермский НИИСХ), 614532, Пермский край, Пермский район, с. Лобаново, ул. Культуры, 12; e-mail: pniish@ rambler.ru

Матолинеи Дарья Анатольевна, научный сотрудник лаборатории кормопроизводства, животноводства и ветеринарной медицины, Пермский НИИСХ; e-mail: pniish @rambler.ru

Сергеев Игорь Викторович, аспирант кафедры животноводства, Пермский государственный аграрно-технологический университет им. академика Д.Н. Прянишникова (Пермский ГАТУ), 614990, г. Пермь, ул. Петропавловская, 23; e-mail: likruser@yandex.ru 